\title{
Facile synthesis of carbon-11-labeled sEH/PDE4 dual inhibitors as new potential PET agents for imaging of sEH/PDE4 enzymes in neuroinflammation
}

\author{
Limeng Jia ${ }^{\mathrm{a}}$, Caihong Miao ${ }^{\mathrm{a}}$, Fugui Dong ${ }^{\mathrm{a}}$, Wei Li ${ }^{\mathrm{a}}$, Min Wang ${ }^{\mathrm{b}}$, Qi-Huang Zheng,*, \\ Zhidong $\mathrm{Xu}^{\mathrm{a}, \mathrm{c}, \mathrm{d} *}$ \\ ${ }^{a}$ Key Laboratory of Medicinal Chemistry and Molecular Diagnosis of Ministry of Education, College of Chemistry and \\ Environmental Science, Hebei University, Baoding, Hebei 071002, China \\ ${ }^{b}$ Department of Radiology and Imaging Sciences, Indiana University School of Medicine, 1345 West $16^{\text {th }}$ Street, Room 202, \\ Indianapolis, IN 46202, USA \\ ${ }^{c}$ College of Chemical \& Pharmaceutical Engineering, Key Laboratory of Molecular Chemistry for Medicine of Hebei \\ Province, Hebei University of Science \& Technology, Shijiazhuang, Hebei 050018, China \\ ${ }^{d}$ Shijiazhuang Vince Pharmatech Co., Ltd., Shijiazhuang, Hebei 050030, China
}

*Corresponding authors. E-mail address: qzheng@iupui.edu (Q.-H. Zheng); zhidongxu@hbu.edu.cn (Z. Xu).

This is where the receipt/accepted dates will go; Received Month XX, 2019; Accepted Month XX, 2019 [BMCL RECEIPT]

\begin{abstract}
To develop PET tracers for imaging of neuroinflammation, new carbon-11-labeled sEH/PDE4 dual inhibitors have been synthesized. The reference standard $N$-(4-methoxy-2-(trifluoromethyl)benzyl)benzamide (1) and its corresponding desmethylated precursor $\quad N$-(4-hydroxy-2-(trifluoromethyl)benzyl)benzamide (2) were synthesized from (4-methoxy-2(trifluoromethyl)phenyl)methanamine and benzoic acid in one and two steps with $84 \%$ and $49 \%$ overall chemical yield, respectively. The standard $N$-(4-methoxy-2-(trifluoromethyl)benzyl)-1-propionylpiperidine-4-carboxamide (MPPA, 4) and its precursor N-(4-hydroxy-2(trifluoromethyl)benzyl)-1-propionylpiperidine-4-carboxamide (5) were synthesized from methyl 4-piperidinecarboxylate, propionyl chloride and (4-methoxy-2-(trifluoromethyl)phenyl)methanamine in two and three steps with $62 \%$ and $34 \%$ overall chemical yield, respectively. The target tracers $N$ - $\left(4-\left[{ }^{11} \mathrm{C}\right]\right.$ methoxy-2-(trifluoromethyl)benzyl)benzamide $\left(\left[{ }^{11} \mathrm{C}\right] \mathbf{1}\right)$ and $N-\left(4-\left[{ }^{11} \mathrm{C}\right]\right.$ methoxy-2(trifluoromethyl)benzyl)-1-propionylpiperidine-4-carboxamide $\left(\left[{ }^{11} \mathrm{C}\right] \mathrm{MPPA},\left[{ }^{11} \mathrm{C}\right] 4\right)$ were prepared from their corresponding precursors 2

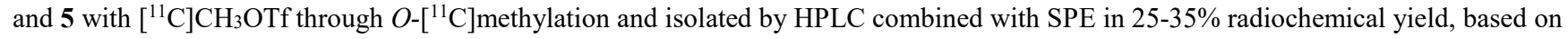
$\left[{ }^{11} \mathrm{C} \mathrm{CO}_{2}\right.$ and decay corrected to end of bombardment (EOB). The radiochemical purity was $>99 \%$, and the molar activity (AM) at EOB was $370-740 \mathrm{GBq} / \mu \mathrm{mol}$ with a total synthesis time of $35-40$-minutes from EOB.
\end{abstract}

Keywords: Soluble epoxide hydrolase (sEH); Phosphodiesterase 4 (PDE4); Carbon-11-labeled sEH/PDE4 dual inhibitors; Radiosynthesis; Positron emission tomography (PET); Neuroinflammation.

Inflammation is a complex biological process and part of the body's immune response involving immune cells, blood vessels, and molecular mediators for selfprotection to remove harmful stimuli, including damaged cells, irritants, or pathogens. ${ }^{1}$ Neuroinflammation is the inflammation of the nervous tissue, and it is associated with central nervous system (CNS) diseases including Alzheimer's disease (AD), Parkinson's disease (PD), Huntington's disease (HD), multiple sclerosis (MS), amyotrophic lateral sclerosis (ALS), traumatic brain injury (TBI) and stroke. ${ }^{1-4}$ Molecular imaging of neuroinflammation in

This is the author's manuscript of the article published in final edited form as:

Jia, L., Miao, C., Dong, F., Li, W., Wang, M., Zheng, Q.-H., \& Xu, Z. (2019). Facile synthesis of carbon-11-labeled sEH/PDE4 dual inhibitors as new potential PET agents for imaging of sEH/PDE4 enzymes in neuroinflammation. Bioorganic \& Medicinal Chemistry Letters, 29(13), 1654-1659. https://doi.org/10.1016/j.bmcl.2019.04.036 
neurodegenerative diseases by positron emission tomography (PET) is one of the most active as well as most challenging areas in neuroscience, because PET neuroimaging can offer various non- or minimally invasive techniques to characterize neuroinflammatory processes for the purpose of diagnosis, therapy and treatment monitoring. ${ }^{5-8}$ Many enzyme- or receptorbased radioligands have been developed for in vivo PET visualization of neuroinflammation. ${ }^{9-11}$ We are interested in the development of new PET radioligands for neuroinflammation. In our previous work, we have synthesized and developed a series of PET radiotracers ${ }^{12-20}$ that target the enzyme or receptor for neuroinflammation such as $\left[{ }^{11} \mathrm{C}\right] \mathrm{FMAME}$ for matrix metalloproteinase (MMP), carbon-11-labeled celecoxib derivatives for cyclooxygenase-2 (COX-2), $\left[{ }^{11} \mathrm{C}\right] \mathrm{PBR} 28$ for translocator protein (TSPO), $\left[{ }^{11} \mathrm{C}\right] \mathrm{MCFA}$ for cannabinoid receptor $2(\mathrm{CB} 2),\left[{ }^{11} \mathrm{C}\right] \mathrm{SB}-216763$ for glycogen synthase kinase 3 (GSK-3), $\left[{ }^{11} \mathrm{C}\right] \mathrm{MABL}$ for $\mathrm{CX}_{3} \mathrm{C}$ chemokine receptor $1 \quad\left(\mathrm{CX}_{3} \mathrm{CR} 1\right)$, $\left[{ }^{11} \mathrm{C}\right] \mathrm{GSK} 1482160$ for purinergic receptor $\left(\mathrm{P}_{2} \mathrm{X}_{7}\right)$ and $\left.{ }^{11} \mathrm{C}\right] \mathrm{MMPC}$ for interleukin-1 receptor-associated kinase 4 (IRAK4), as indicated in Figure 1. Traditionally drugs including PET drugs have been designed based on single-target approach, however, in complex diseases where single-target drugs have failed or show severe limitations, multi-target drugs have emerged as more effective therapeutic approach, since drug molecules often interact with multiple targets. ${ }^{21-24}$ Subsequently, PET radioligand design has benefited from the multitarget approach in drug design and discovery, which opens new avenues to rationally develop next generation of more effective PET agents. In this ongoing study, we first select the dual enzymes soluble epoxide hydrolase (sEH)/phosphodiesterase 4 (PDE4) as another more specific neuroinflammatory target for PET imaging. Both sEH and PDE4 are critical enzymes in neuroinflammation and play an important role in the progression of various neurodegenerative diseases including $\mathrm{AD}{ }^{25}$ Small drug molecules targeting on multiple proteins have attracted tremendous interest for developing therapeutics, and dual sEH/PDE4 inhibitors for the treatment of inflammatory diseases represent this multi-target therapeutic strategy. To improve the treatment of complex diseases, multitarget ligands have been designed and developed. ${ }^{26}$ Recently, bioavailable sEH/PDE4 dual inhibitors have been developed to treat inflammatory pain, the representative compound $\mathrm{N}$-(4methoxy-2-(trifluoromethyl)benzyl)-1-

propionylpiperidine-4-carboxamide (MPPA, 4) displayed good efficacy in in vitro assays with $\mathrm{IC}_{50} 2.1$ $\mathrm{nM}(\mathrm{hsEH})$ and $8.1 \mathrm{nM}$ (PDE4), and a derivative $N$-(4methoxy-2-(trifluoromethyl)benzyl)benzamide

exhibited similar in vitro efficacy with $\mathrm{IC}_{50} 2 \mathrm{nM}$ (hsEH) ${ }^{25}$ Radiolabeled PDE4 inhibitors such as $\left[{ }^{11} \mathrm{C}\right] R$ (-)-Rolipram (Figure 1) have been developed and evaluated in animal and human PET studies. ${ }^{27}$ Likewise, radiolabeled sEH inhibitors like $\left[{ }^{18} \mathrm{~F}\right] \mathrm{FNDP}$ (Figure 1) have been developed and evaluated in animals. ${ }^{28}$ However, the PubMed search showed no records on radiolabeled sEH/PDE4 dual inhibitors. It is clear PET imaging modality can accurately measure the protein expression in biological process and diseases, but it will be still challenging to assess the changes of dual proteins expression level using dual proteins target radiotracers. The key point is that a sEH/PDE4 dual inhibitor should have favorable in vitro biological activity for both protein targets first. Here we report the design, synthesis and labeling of radiolabeled sEH/PDE4 dual inhibitors, $N-\left(4-\left[{ }^{11} \mathrm{C}\right]\right.$ methoxy-2(trifluoromethyl)benzyl)benzamide $\left(\left[{ }^{11} \mathrm{C}\right] \mathbf{1}\right)$ and $N$-(4$\left[{ }^{11} \mathrm{C}\right]$ methoxy-2-(trifluoromethyl)benzyl)-1-

propionylpiperidine-4-carboxamide $\quad\left(\left[{ }^{11} \mathrm{C}\right] \mathrm{MPPA}\right.$, $\left[{ }^{11} \mathrm{C}\right]$ 4) (Figure 1), as new candidate PET neuroinflammation imaging agents, for the first time.

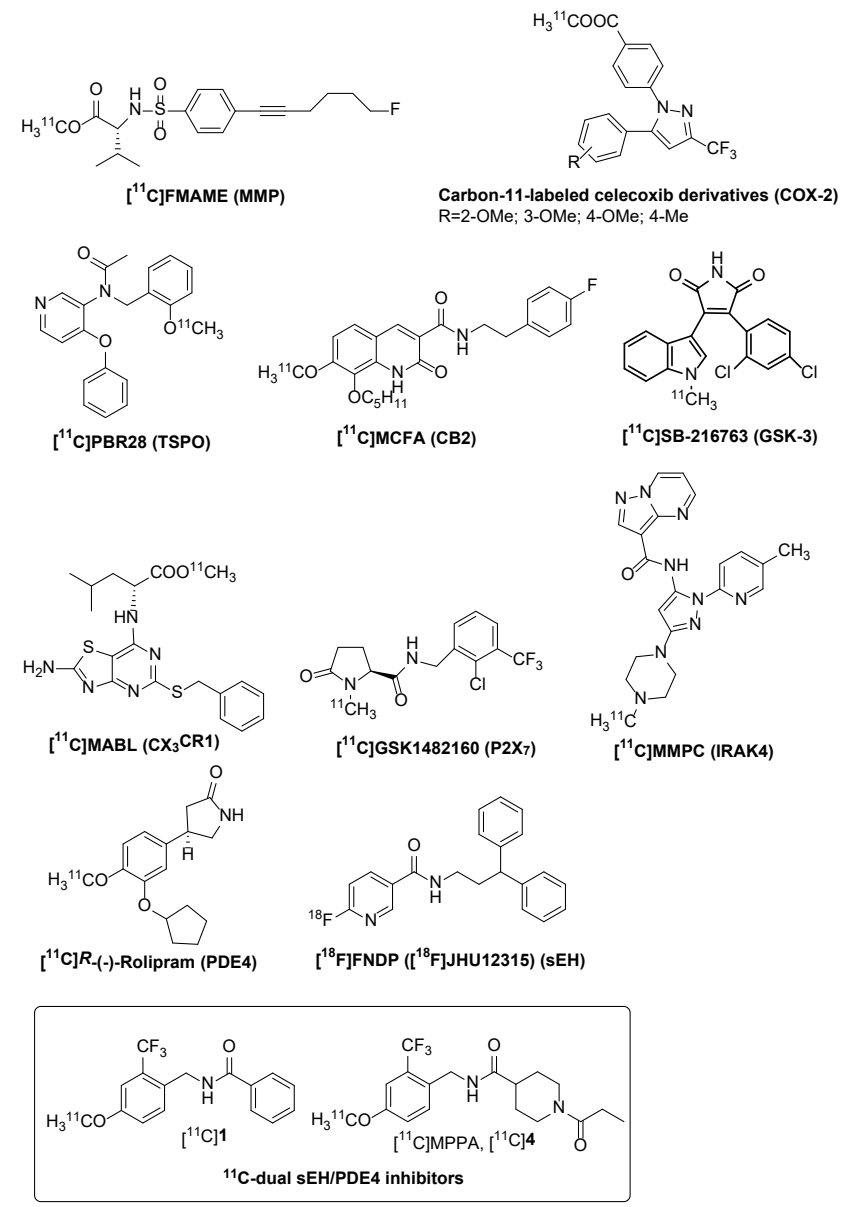

Figure 1. PET radiotracers for imaging of neuroinflammation.

$\mathrm{IC}_{50}$ values for $\left[{ }^{11} \mathrm{C}\right] \mathrm{MPPA}$ are $2.1 \mathrm{nM}(\mathrm{hsEH})$ and 8.1 $\mathrm{nM}$ (PDE4), ${ }^{25}$ compared to previously reported $\left[{ }^{18} \mathrm{~F}\right]$ FNDP $\left(\mathrm{IC}_{50} 8.66 \mathrm{nM} \text { for } \mathrm{sEH}\right)^{28}$ and $\left[{ }^{11} \mathrm{C}\right] R-(-)-$ Rolipram ( $\mathrm{IC}_{50} 290 \mathrm{nM}$ for PDE4), ${ }^{29}$ the results suggest the imaging probes developed in this study have 
superior in vitro biological data to $\left[{ }^{11} \mathrm{C}\right] R-(-)$-Rolipram and $\left[{ }^{18} \mathrm{~F}\right] \mathrm{FNDP}$.

Synthesis of the reference standards $1, \mathbf{4}$; and their corresponding desmethylated precursors $N$-(4-hydroxy2-(trifluoromethyl)benzyl)benzamide (2), $\quad N$-(4hydroxy-2-(trifluoromethyl)benzyl)-1-

propionylpiperidine-4-carboxamide (5) is depicted in Scheme 1, according to the reported procedures. ${ }^{25,30-34}$ Compounds 1 and $\mathbf{4}$ were prepared by an amidation reaction from commercially procured (4-methoxy-2(trifluoromethyl)phenyl)methanamine and benzoic acid or propionylpiperidine-4-carboxylic acid (3) in the presence of 1-ethyl-3-(3-(dimethylamino)propyl)carbodiimide (EDC) and 4-(dimethylamino)pyridine (DMAP) in $84 \%$ and $70 \%$ yield, respectively. Compound 3 was prepared from 4piperidinecarboxylate through an amidation reaction with propionyl chloride, and then hydrolyzed with aqueous $\mathrm{NaOH}$ in $88 \%$ yield. The desmethylated precursors $\mathbf{2}$ and $\mathbf{5}$ were obtained by desmethylation reaction of the reference standards 1 and 4 with $\mathrm{BBr}_{3}$ in $\mathrm{CH}_{2} \mathrm{Cl}_{2}$ at $0{ }^{\circ} \mathrm{C}$ in $59 \%$ and $55 \%$ yield, respectively.

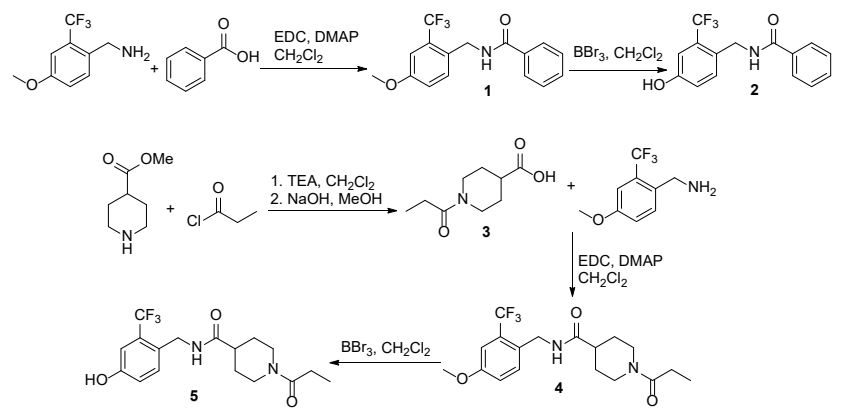

Scheme 1. Synthesis of reference standards 1, 4 and precursors 2, 5 .

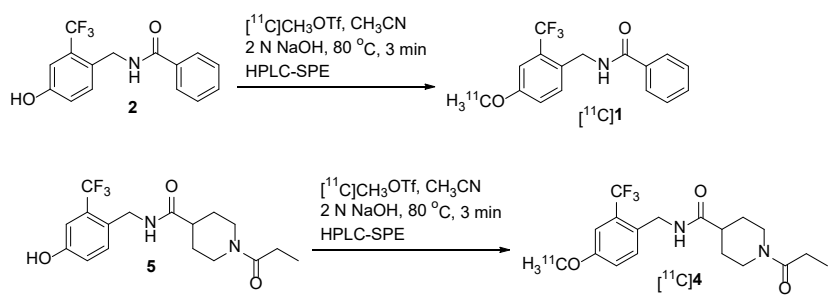

Scheme 2. Synthesis of target tracers $\left[{ }^{11} \mathrm{C}\right] 1$ and $\left[{ }^{11} \mathrm{C}\right] 4$.

Synthesis of the target tracers $\left[{ }^{11} \mathrm{C}\right] \mathbf{1}$ and $\left[{ }^{11} \mathrm{C}\right] \mathbf{4}$ is presented in Scheme 2. The desmethylated precursor 2 or 5 underwent $O-\left[{ }^{11} \mathrm{C}\right]$ methylation ${ }^{35}$ using the reactive $\left[{ }^{11} \mathrm{C}\right]$ methylating agent $\quad\left[{ }^{11} \mathrm{C}\right]$ methyl triflate $\left(\left[{ }^{11} \mathrm{C}\right] \mathrm{CH}_{3} \mathrm{OTf}\right)^{36,37}$ in acetonitrile at $80{ }^{\circ} \mathrm{C}$ under basic conditions $(2 \mathrm{~N} \mathrm{NaOH})$. The product was isolated by semi-preparative reverse-phase (RP) high performance liquid chromatography (HPLC) with a C-18 column, and then concentrated by solid-phase extraction (SPE) with a disposable C-18 Plus Sep-Pak cartridge to produce the corresponding pure radiolabeled compound $\left[{ }^{11} \mathrm{C}\right] 1$ or $\left[{ }^{11} \mathrm{C}\right] 4$ in $25-35 \%$ radiochemical yield, decay corrected to end of bombardment (EOB), based on $\left[{ }^{11} \mathrm{C}\right] \mathrm{CO}_{2}$.

The radiosynthesis was performed in a home-built automated multi-purpose $\quad\left[{ }^{11} \mathrm{C}\right]$-radiosynthesis module. ${ }^{38-40}$ Our radiosynthesis module facilitated the overall design of the reaction, purification and reformulation capabilities in a fashion suitable for adaptation to preparation of human doses. The radiosynthesis includes three stages: 1) labeling reaction; 2) purification; and 3) formulation. The overall synthesis time was 35-40 min from EOB. Our module is also designed to allow in-process measurement of $\left[{ }^{11} \mathrm{C}\right]-$ tracer molar activity $\left(\mathrm{A}_{\mathrm{M}}, \mathrm{GBq} / \mu \mathrm{mol}\right.$ at $\left.\mathrm{EOB}\right)$ using a radiation detector with a UV detector at the outlet of the HPLC-portion of the system. At the end of synthesis (EOS), the $\mathrm{A}_{\mathrm{M}}$ of $\left[{ }^{11} \mathrm{C}\right]$-tracer was determined again by analytical RP-HPLC, calculated, decay corrected to $\mathrm{EOB}$, and based on $\left[{ }^{11} \mathrm{C}\right] \mathrm{CO}_{2}$, which was in agreement with the 'on line' determined value. The $A_{M}$ of $\left[{ }^{11} \mathrm{C}\right] \mathbf{1}$ and $\left[{ }^{11} \mathrm{C}\right] 4$ produced in our PET chemistry facility was in the range of $370-740 \mathrm{GBq} / \mu \mathrm{mol}$ at $\mathrm{EOB}$, using the Siemens RDS-111 Eclipse cyclotron ${ }^{11} \mathrm{C}$-gas target, the Eckert \& Ziegler Modular Lab C-11 Methyl Iodide/Triflate module, and our $\left[{ }^{11} \mathrm{C}\right]$-radiosynthesis unit. $^{35}$

Chemical purity and radiochemical purity were determined by analytical RP-HPLC. ${ }^{41}$ The chemical purity of the precursor and reference standard was $>90 \%$ determined by RP-HPLC through UV flow detector. A representative analytical RP-HPLC chromatographic profile for the tracers $\left[{ }^{11} \mathrm{C}\right] \mathbf{1}$ and $\left[{ }^{11} \mathrm{C}\right] 4$, Radio-HPLC (A) and UV-HPLC (B) traces for $\left[{ }^{11} \mathrm{C}\right]$ 1; Radio-HPLC (C) and UV-HPLC (D) traces for $\left[{ }^{11} \mathrm{C}\right]$ 4, is shown in Figure 2. The radiochemical purity of the target tracer $\left[{ }^{11} \mathrm{C}\right] \mathbf{1}$ or $\left[{ }^{11} \mathrm{C}\right] \mathbf{4}$ was $>99 \%$ determined by Radio-HPLC through $\gamma$-ray (PIN diode) flow detector as indicated in Figure 2, $\mathbf{A}$ or $\mathbf{C}$. The chemical purity of the target tracer $\left[{ }^{11} \mathrm{C}\right] 1$ or $\left[{ }^{11} \mathrm{C}\right] \mathbf{4}$ was simultaneously determined by UV-HPLC through UV flow detector as indicated in Figure 2, B or D. The minor impurities included its corresponding labeling precursor $\mathbf{2}$ or $\mathbf{5}$ and a few unknown UV peaks from the saline used in tracer formulation after HPLC-SPE purification. However, there is no chemical purity of the tracer release limit in PET tracer production, because the radiosynthesis is a micro-scale synthesis, and the radiotracer prepared is very trace amount.

The stability of the labeled tracers $\left[{ }^{11} \mathrm{C}\right] \mathbf{1}$ and $\left[{ }^{11} \mathrm{C}\right] \mathbf{4}$ was evaluated by analytical HPLC from EOS up to $3 \mathrm{~h}$, one injection of the tracer solution in $\mathrm{EtOH} / \mathrm{saline}$ onto HPLC column per hour. The HPLC chromatograms showed $\left[{ }^{11} \mathrm{C}\right] \mathbf{1}$ and $\left[{ }^{11} \mathrm{C}\right] \mathbf{4}$ were stable without decomposition. 
A. Analytical radioactive HPLC trace for $\left[{ }^{11} \mathrm{C}\right] 1$, Retention time $\left(\mathrm{t}_{\mathrm{R}}\right)=6.64 \mathrm{~min}$

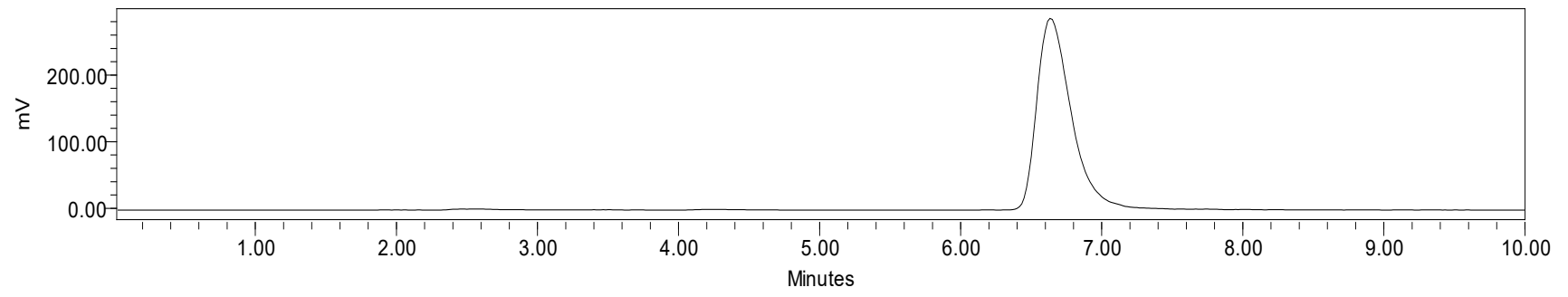

B. Analytical UV HPLC trace for $\left[{ }^{11} \mathrm{C}\right] 1, \mathrm{t}_{\mathrm{R}}=6.56 \mathrm{~min}$

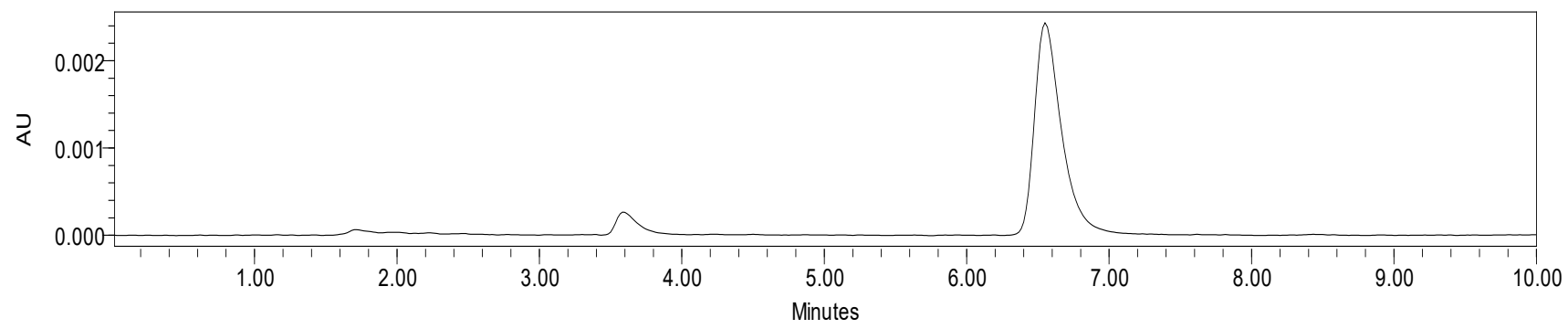

C. Analytical radioactive HPLC trace for $\left[{ }^{11} \mathrm{C}\right] \mathbf{4}, \mathrm{t}_{\mathrm{R}}=4.31 \mathrm{~min}$

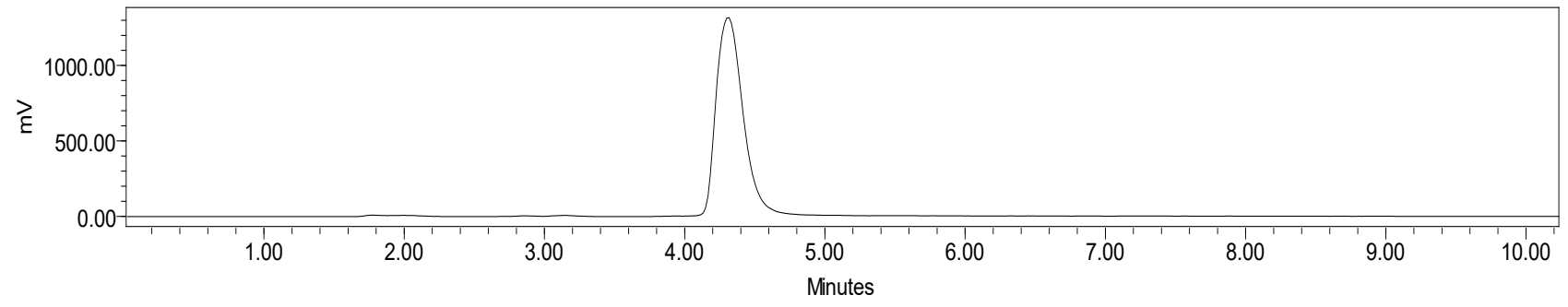

D. Analytical UV HPLC trace for $\left[{ }^{11} \mathrm{C}\right] 4, \mathrm{t}_{\mathrm{R}}=4.23 \mathrm{~min}$

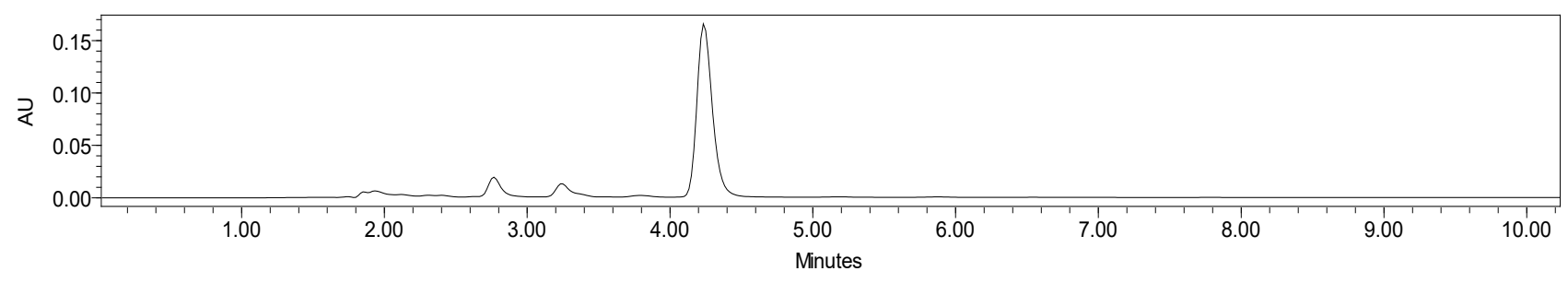

Figure 2. A representative analytical RP-HPLC chromatographic profile for the tracers $\left[{ }^{11} \mathrm{C}\right] \mathbf{1}$ and $\left[{ }^{11} \mathrm{C}\right] 4$ : (A) Radio-HPLC trace for $\left[{ }^{11} \mathrm{C}\right] \mathbf{1}$ and (B) UV-HPLC trace for $\left[{ }^{11} \mathrm{C}\right] \mathbf{1}$; (C) Radio-HPLC trace for $\left[{ }^{11} \mathrm{C}\right] 4$ and (D) UV-HPLC trace for $\left[{ }^{11} \mathrm{C}\right] 4$. Analytical RP-HPLC conditions were a Prodigy (Phenomenex) $5 \mu \mathrm{m} \mathrm{C}-18$ column, $4.6 \times 250 \mathrm{~mm}$; mobile phase $65 \% \mathrm{CH}_{3} \mathrm{CN} / 35 \% 4.0 \mathrm{mM}$ $\mathrm{CH}_{3} \mathrm{COONa}$; flow rate $1.0 \mathrm{~mL} / \mathrm{min}$; $\mathrm{UV}(254 \mathrm{~nm})$ and $\gamma$-ray (PIN diode) flow detectors. 
The experimental details and characterization data for compounds $\mathbf{1 - 5}$ and for the tracers $\left[{ }^{11} \mathrm{C}\right] \mathbf{1}$ and $\left[{ }^{11} \mathrm{C}\right] \mathbf{4}$ are given. ${ }^{42}$

In summary, facile synthetic routes with moderate to high yields have been developed to produce the reference standards 1 and 4, desmethylated precursors 2 and $\mathbf{5}$, and target tracers $\left[{ }^{11} \mathrm{C}\right] \mathbf{1}$ and $\left[{ }^{11} \mathrm{C}\right] \mathbf{4}$. The radiosynthesis employed $\left[{ }^{11} \mathrm{C}\right] \mathrm{CH}_{3} \mathrm{OTf}$ for $O$ $\left[{ }^{11} \mathrm{C}\right]$ methylation at the phenol hydroxyl position of the desmethylated precursor, followed by product purification and isolation using a semi-preparative $\mathrm{RP}$ HPLC combined with SPE. $\left[{ }^{11} \mathrm{C}\right] \mathbf{1}$ and $\left[{ }^{11} \mathrm{C}\right] \mathbf{4}$ were obtained in high radiochemical yield, radiochemical purity and chemical purity, with a reasonably short overall synthesis time, and high molar activity. This will facilitate studies to evaluate $\left[{ }^{11} \mathrm{C}\right] 1$ and $\left[{ }^{11} \mathrm{C}\right] 4$ as new potential PET agents for imaging of sEH and PDE4 enzymes in neuroinflammation.

\section{Acknowledgments}

This work was partially supported by the Hebei Province Major Science and Technology Program (No. 17392605D), and the High Level Scientific and Technological Innovation and Entrepreneurial Talent Plan of Shijiazhuang in China. This work was also partially supported by the Indiana University Department of Radiology and Imaging Sciences in the United States.

\section{References and notes}

1. Heukels P, Moor CC, von der Thüsen JH, Wijsenbeek MS, Kool M. Inflammation and immunity in IPF pathogenesis and treatment. Respir Med. 2019;147:7991.

2. Knezevic D, Mizrahi R. Molecular imaging of neuroinflammation in Alzheimer's disease and mild cognitive impairment. Prog Neuropsychopharmacol Biol Psychiatry. 2018;80(Pt B):123-131.

3. Chen WW, Zhang X, Huang WJ. Role of neuroinflammation in neurodegenerative diseases (Review). Mol Med Rep. 2016;13:3391-3396.

4. Kielian T. Neuroinflammation: good, bad, or indifferent? J Neurochem. 2014;130:1-3.

5. Calsolaro V, Edison P. Neuroinflammation in Alzheimer's disease: Current evidence and future directions. Alzheimer's Dement. 2016;12:719732 .

6. Cerami C, Iaccarino L, Perani D. Molecular imaging of neuroinflammation in neurodegenerative dementias: The role of in vivo PET imaging. Int J Mol Sci. 2017;18: E993.
7. Schain M, Kreisl WC. Neuroinflammation in neurodegenerative disorders-a review. Curr Neurol Neurosci Rep. 2017;17:25.

8. Albrecht DS, Granziera C, Hooker JM, Loggia ML. In vivo imaging of human neuroinflammation. ACS Chem Neurosci. 2016;7:470-483.

9. Gargiulo S, Coda AR, Panico M, Gramanzini M, Moresco RM, Chalon S, Pappatà S. Molecular imaging of neuroinflammation in preclinical rodent models using positron emission tomography. Q J Nucl Med Mol Imaging. 2017;61:60-75.

10. Ory D, Celen S, Verbruggen A, Bormans G. PET radioligands for in vivo visualization of neuroinflammation. Curr Pharm Des. 2014;20:58975913.

11. Narayanaswami V, Dahl $\mathrm{K}$, Bernard-Gauthier $\mathrm{V}$, Josephson L, Cumming P, Vasdev N. Emerging PET radiotracers and targets for imaging of neuroinflammation in neurodegenerative diseases: Outlook beyond TSPO. Mol Imaging. 2018;17:1-25.

12. Zheng Q.-H, Fei X, DeGrado TR, Wang JQ, Stone KL, Martinez TD, Gay DJ, Baity WL, Mock BH, Glick-Wilson BE, Sullivan ML, Miller KD, Sledge GW, Hutchins GD. Synthesis, biodistribution and micro-PET imaging of a potential cancer biomarker carbon-11 labeled MMP inhibitor (2R)-2-[[4-(6fluorohex-1-ynyl)phenyl]sulfonylamino]-3-

methylbutyric acid $\left[{ }^{11} \mathrm{C}\right]$ methyl ester. Nucl Med Biol. 2003;30:753-760.

13. Gao M, Wang M, Miller KD, Zheng Q.-H. Synthesis and preliminary in vitro biological evaluation of new carbon-11-labeled celecoxib derivatives as candidate PET tracers for imaging of COX-2 expression in cancer. Eur J Med Chem. 2011;46:4760-4767.

14. Wang M, Yoder KK, Gao M, Mock BH, Xu XM, Saykin AJ, Hutchins GD, Zheng Q.-H. Fully automated synthesis and initial PET evaluation of $\left[{ }^{11}\right.$ C]PBR28. Bioorg Med Chem Lett. 2009;19:56365639.

15. Gao M, Wang M, Miller KD, Hutchins GD, Zheng Q.H. Synthesis and in vitro biological evaluation of carbon-11-labeled quinoline derivatives as new candidate PET radioligands for cannabinoid CB2 receptor imaging. Bioorg Med Chem. 2010;18:20992106.

16. Wang M, Gao M, Miller KD, Sledge GW, Hutchins GD, Zheng Q.-H. The first synthesis of $\left[{ }^{11} \mathrm{C}\right] \mathrm{SB}-$ 216763, a new potential PET agent for imaging of glycogen synthase kinase-3 (GSK-3). Bioorg Med Chem Lett. 2011;21:245-249.

17. Gao M, Wang M, Meyer JA, Peters JS, Zarrinmayeh H, Territo PR, Hutchins GD, Zheng Q.-H. Synthesis and preliminary biological evaluation of $\left[{ }^{11} \mathrm{C}\right]$ methyl (2-amino-5-(benzylthio)thiazolo[4,5-d]pyrimidin-7$\mathrm{yl})$-d-leucinate for the fractalkine receptor $\left(\mathrm{CX}_{3} \mathrm{CR} 1\right)$. Bioorg Med Chem Lett. 2017;27:2727-2730.

18. Gao M, Wang M, Green MA, Hutchins GD, Zheng Q.-H. Synthesis of $\left[{ }^{11} \mathrm{C}\right] \mathrm{GSK} 1482160$ as a new PET 
agent for targeting $\mathrm{P} 2 \mathrm{X}_{7}$ receptor. Bioorg Med Chem Lett. 2015;25:1965-1970.

19. Territo PR, Meyer JA, Peters JS, Riley AA, McCarthy BP, Gao M, Wang M, Green MA, Zheng Q.-H, Hutchins GD. Characterization of ${ }^{11}$ C-GSK1482160 for targeting the $\mathrm{P} 2 \mathrm{X} 7$ receptor as a biomarker for neuroinflammation. J Nucl Med. 2017;58:458-465.

20. Wang X, Xu W, Miao C, Dong F, Li W, Wang M, Gao M, Zheng Q.-H, Xu Z. Synthesis of $N-(3-(4-$ $\left[{ }^{11} \mathrm{C}\right]$ methylpiperazin-1-yl)-1-(5-methylpyridin-2-yl)$1 H$-pyrazol-5-yl)pyrazolo[1,5-a]pyrimidine-3carboxamide as a new potential PET agent for imaging of IRAK4 enzyme in neuroinflammation. Appl Radiat Isot. 2018;132:6-12.

21. Espinoza-Fonseca LM. The benefits of the multitarget approach in drug design and discovery. Bioorg Med Chem. 2006;14:896-897.

22. Talevi A. Multi-target pharmacology: possibilities and limitations of the "skeleton key approach" from a medicinal chemist perspective. Front Pharmacol. 2015;6:205.

23. Ramsay RR, Popovic-Nikolic MR, Nikolic K, Uliassi E, Bolognesi ML. A perspective on multi-target drug discovery and design for complex diseases. Clin Transl Med. 2018;7:3.

24. Reddy AS, Zhang S. Polypharmacology: drug discovery for the future. Expert Rev Clin Pharmacol. 2013;6:41-7.

25. Blöcher R, Wagner KM, Gopireddy RR, Harris TR, Wu H, Barnych B, Hwang SH, Xiang YK, Proschak E, Morisseau C, Hammock BD. Orally available soluble epoxide hydrolase/phosphodiesterase 4 dual inhibitor treats inflammatory pain. $\mathrm{J}$ Med Chem. 2018;61:3541-3550.

26. Ibrahim MM, Gabr MT. Multitarget therapeutic strategies for Alzheimer's disease. Neural Regen Res. 2019;14:437-440.

27. Kenk M, Thomas A, Lortie M, Dekemp R, Beanlands RS, Dasilva JN. PET measurements of cAMPmediated phosphodiesterase-4 with $(R)-\left[{ }^{11} \mathrm{C}\right]$ rolipram. Curr Radiopharm. 2011;4:44-58.

28. Horti AG, Wang Y, Minn I, Lan X, Wang J, Koehler RC, Alkayed NJ, Dannals RF, Pomper MG. ${ }^{18}$ F-FNDP for PET imaging of soluble epoxide hydrolase. J Nucl Med. 2016;57:1817-1822.

29. Souness JE, Griffin M, Maslen C, Ebsworth K, Scott LC, Pollock K, Palfreyman MN, Karlsson JA. Evidence that cyclic AMP phosphodiesterase inhibitors suppress TNF alpha generation from human monocytes by interacting with a 'low-affinity' phosphodiesterase 4 conformer. $\mathrm{Br} \mathrm{J}$ Pharmacol. 1996;118:649-658.

30. Blöcher R, Lamers C, Wittmann SK, Merk D, Hartmann M, Weizel L, Diehl O, Brüggerhoff A, Boß M, Kaiser A, Schader T, Göbel T, Grundmann M, Angioni C, Heering J, Geisslinger G, Wurglics M, Kostenis E, Brüne B, Steinhilber D, SchubertZsilavecz M, Kahnt AS, Proschak E. $N$ Benzylbenzamides: A novel merged scaffold for orally available dual soluble epoxide hydrolase/peroxisome proliferator-activated receptor gamma modulators. J Med Chem. 2016;59:61-81.

31. Jiang L, Yu J, Niu F, Zhang D, Sun X. A highefficient method for the amidation of carboxylic acids promoted by triphenylphosphine oxide and oxalyl chloride. Heteroatom Chem. 2017;28:e21364.

32. Aiello F, Shabaik Y, Esqueda A, Sanchez TW, Grande F, Garofalo A, Neamati N. Design and synthesis of 3carbamoylbenzoic acid derivatives as inhibitors of human apurinic/apyrimidinic endonuclease 1 (APE1). ChemMedChem. 2012;7:1825-1839.

33. Yan YL, Miller MT, Cao Y, Cohen SM. Synthesis of hydroxypyrone- and hydroxythiopyrone-based matrix metalloproteinase inhibitors: developing a structureactivity relationship. Bioorg Med Chem Lett. 2009; 19:1970-1976.

34. Zhao Z, Pissarnitski DA, Josien HB, Bara TA, Clader $\mathrm{JW}, \mathrm{Li} \mathrm{H}, \mathrm{McBriar} \mathrm{MD}$, Rajagopalan $\mathrm{M}, \mathrm{Xu} \mathrm{R}$, Terracina G, Hyde L, Song L, Zhang L, Parker EM, Osterman R, Buevich AV. Substituted 4-morpholine $\mathrm{N}$-arylsulfonamides as $\gamma$-secretase inhibitors. Eur $\mathbf{J}$ Med Chem. 2016;124:36-48.

35. Gao M, Wang M, Zheng Q.-H. Synthesis of carbon11-labeled CK1 inhibitors as new potential PET radiotracers for imaging of Alzheimer's disease. Bioorg Med Chem Lett. 2018;28:2234-2238.

36. Jewett DM. A simple synthesis of $\left[{ }^{11} \mathrm{C}\right]$ methyl triflate. Int J Rad Appl Instrum A. 1992;43:1383-1385.

37. Mock BH, Mulholland GK, Vavrek MT. Convenient gas phase bromination of $\left[{ }^{11} \mathrm{C}\right]$ methane and production of $\left[{ }^{11} \mathrm{C}\right]$ methyl triflate. Nucl Med Biol. 1999;26:467471.

38. Wang M, Gao M, Zheng Q.-H. Fully automated synthesis of PET TSPO radioligands $\left[{ }^{11} \mathrm{C}\right] \mathrm{DAA} 1106$ and $\left[{ }^{18}\right.$ F]FEDAA1106. Appl Radiat Isot. 2012;70:965973.

39. Mock BH, Zheng Q.-H, DeGrado TR. A multipurpose ${ }^{11} \mathrm{C}$-radio-synthesis system. J Labelled Compd Radiopharm. 2005;48:S225.

40. Mock BH, Glick-Wilson BE, Zheng Q.-H, DeGrado TR. Automated measurement of specific activity of radiolabeled ligands during synthesis. J Labelled Compd Radiopharm. 2005;48:S224.

41. Zheng Q.-H, Mock BH. Purification of carbon-11 PET radiotracers from unlabeled precursors by preparative HPLC and SPE. Biomed Chromatogr. 2005;19:671676.

42. (a). General: All commercial reagents and solvents were purchased from Sigma-Aldrich and Fisher Scientific, and used without further purification. $\left[{ }^{11} \mathrm{C} \mathrm{CH}_{3} \mathrm{OTf}\right.$ was prepared according to a literature procedure. ${ }^{37}$ Melting points were determined on WRR apparatus and were uncorrected. ${ }^{1} \mathrm{H}$ and ${ }^{13} \mathrm{C}$ NMR spectra were recorded on a Bruker Avance II 600 or $400 \mathrm{MHz}$ NMR Fourier transform spectrometer at 600 or $100 \mathrm{MHz}$, respectively. Chemical shifts $(\delta)$ are reported in parts per million (ppm) relative to an internal standard tetramethylsilane (TMS, $\delta 0.0)\left({ }^{1} \mathrm{H}\right.$ 
NMR) and to the solvent signal $\left({ }^{13} \mathrm{C}\right.$ NMR), and coupling constants $(J)$ are reported in hertz $(\mathrm{Hz})$. Liquid chromatography-mass spectra (LC-MS) analysis was performed on AB Sciex 4000Q Trap instrument, consisting of an 1100 series HPLC connected to a diode array detector and a 1946D mass spectrometer configured for positive-ion/negative-ion electrospray ionization (ESI). The high resolution mass spectra (HRMS) were obtained using a Waters/Micromass LCT Classic spectrometer. Chromatographic solvent proportions are indicated as volume : volume ratio. Thin-layer chromatography (TLC) was run using HS silica gel GF254 uniplates (5 $\times 10 \mathrm{~cm}^{2}$ ). Plates were visualized under UV light. Normal phase flash column chromatography was carried out on Combiflash Rf 150 silica gel 60 (300400 mesh) with a forced flow of the indicated solvent system in the proportions described below. All moisture- and air-sensitive reactions were performed under a positive pressure of nitrogen maintained by a direct line from a nitrogen source. Analytical RPHPLC was performed using a Prodigy (Phenomenex) $5 \mu \mathrm{m} \mathrm{C}-18$ column, $4.6 \times 250 \mathrm{~mm}$; mobile phase $65 \%$ $\mathrm{CH}_{3} \mathrm{CN} / 35 \% 4.0 \mathrm{mM} \mathrm{CH} \mathrm{CH}_{3} \mathrm{COONa}$; flow rate 1.0 $\mathrm{mL} / \mathrm{min}$; UV (254 $\mathrm{nm}$ ) and $\gamma$-ray (PIN diode) flow detectors. Semi-preparative RP-HPLC column was performed using a Prodigy (Phenomenex) $5 \mu \mathrm{m} \mathrm{C}-18$ column, $10 \times 250 \mathrm{~mm} ; 70 \% \mathrm{CH}_{3} \mathrm{CN} / 30 \% \mathrm{H}_{2} \mathrm{O}$ mobile phase; 5 and $4 \mathrm{~mL} / \mathrm{min}$ flow rate for $\left[{ }^{11} \mathrm{C}\right] \mathbf{1}$ and $\left[{ }^{11} \mathrm{C}\right] \mathbf{4}$, respectively; UV (254 nm) and $\gamma$-ray (PIN diode) flow detectors. C18 Plus Sep-Pak cartridges were obtained from Waters Corporation (Milford, MA). Sterile Millex-FG $0.2 \mu \mathrm{m}$ filter units were obtained from Millipore Corporation (Bedford, MA).

(b). N-(4-Methoxy-2(trifluoromethyl)benzyl)benzamide (1): To a stirred solution of benzoic acid $(0.2 \mathrm{~g}, 0.85 \mathrm{mmol})$ in dichloromethane $\left(\mathrm{CH}_{2} \mathrm{Cl}_{2}, 10 \mathrm{~mL}\right)$, EDC $(320 \mathrm{mg}$, $2.00 \mathrm{mmol}$ ), and DMAP (40 $\mathrm{mg}, 0.34 \mathrm{mmol}$ ) were added at room temperature (RT) under a nitrogen atmosphere. After the reaction was continued for $1 \mathrm{~h}$, (4-methoxy-2-(trifluoromethyl)phenyl)methanamine

$(160 \mu \mathrm{L}, 0.93 \mathrm{mmol})$ was added, and the reaction was continued at RT for another $24 \mathrm{~h}$. Water $(30 \mathrm{~mL})$ was added to the reaction mixture, and then the resulted solution was extracted with $\mathrm{CH}_{2} \mathrm{Cl}_{2}(3 \times 30 \mathrm{~mL})$. The combined organic layer was washed with $1 \mathrm{~N} \mathrm{NaOH}$ $(3 \times 20 \mathrm{~mL}), 1 \mathrm{~N} \mathrm{HCl}(3 \times 20 \mathrm{~mL})$ and brine $(3 \times 20$ $\mathrm{mL}$ ), dried over anhydrous $\mathrm{Na}_{2} \mathrm{SO}_{4}$ and filtered. The solvent was evaporated under vacuum. The resulted crude product was purified by silica gel column chromatography with petroleum ether (PE)/EtOAc (3:1) as eluent to afford $\mathbf{1}$ as a white solid $(0.22 \mathrm{~g}$, 84\%), mp 106.3-110.7 ${ }^{\circ} \mathrm{C}$. ${ }^{1} \mathrm{H}$ NMR (600 MHz, $\left.\mathrm{CDCl}_{3}\right): \delta 7.75(\mathrm{~d}, J=7.7 \mathrm{~Hz}, 2 \mathrm{H}), 7.57(\mathrm{~d}, J=8.5$ $\mathrm{Hz}, 1 \mathrm{H}), 7.49(\mathrm{t}, J=7.3 \mathrm{~Hz}, 1 \mathrm{H}), 7.42(\mathrm{t}, J=7.6 \mathrm{~Hz}$, $2 \mathrm{H}), 7.18(\mathrm{~d}, J=2.2 \mathrm{~Hz}, 1 \mathrm{H}), 7.03(\mathrm{dd}, J=8.4,1.9$ $\mathrm{Hz}, 1 \mathrm{H}), 6.48(\mathrm{~s}, 1 \mathrm{H}), 4.74(\mathrm{~d}, J=5.9 \mathrm{~Hz}, 2 \mathrm{H}), 3.83$ (s, 3H). (LC-MS, m/z): Calcd for $\mathrm{C}_{16} \mathrm{H}_{15} \mathrm{~F}_{3} \mathrm{NO}_{2}$ $\left([\mathrm{M}+\mathrm{H}]^{+}\right)$310.1, found:310.1.

(c).

$\mathrm{N}-(4-H y d r o x y-2-$

(trifluoromethyl)benzyl)benzamide (2): To a stirred solution of $1(27 \mathrm{mg}, 0.086 \mathrm{mmol})$ in $\mathrm{CH}_{2} \mathrm{Cl}_{2}(5 \mathrm{~mL})$, $\mathrm{BBr}_{3}(50 \mu \mathrm{L}, 0.52 \mathrm{mmol})$ was added slowly at $0{ }^{\circ} \mathrm{C}$, the reaction mixture was warmed up to $\mathrm{RT}$ and continued for $20 \mathrm{~h}$. The reaction mixture was poured into ice water $(10 \mathrm{~mL})$, and then the $\mathrm{CH}_{2} \mathrm{Cl}_{2}$ was removed under reduced pressure. The resulted aqueous solution was extracted with EtOAc $(3 \times 20$ $\mathrm{mL}$ ). The combined organic layer was washed with water, brine, dried over anhydrous $\mathrm{Na}_{2} \mathrm{SO}_{4}$ and filtered. The organic solution was evaporated under vacuum, and the resulted product was purified by silica gel column chromatography with $\mathrm{PE} / \mathrm{EtOAc}$ $(1: 1)$ as eluent to afford 2 as a white solid $(15 \mathrm{mg}$, 59\%), mp 122.5-124 ${ }^{\circ} \mathrm{C} .{ }^{1} \mathrm{H}$ NMR (600 MHz, $\left.\mathrm{CDCl}_{3}\right)$ : $\delta 9.97(\mathrm{~s}, 1 \mathrm{H}), 8.96(\mathrm{t}, J=5.4 \mathrm{~Hz}, 1 \mathrm{H}), 7.90(\mathrm{~d}, J=7.3$ $\mathrm{Hz}, 2 \mathrm{H}), 7.55(\mathrm{t}, J=7.3 \mathrm{~Hz}, 1 \mathrm{H}), 7.48(\mathrm{t}, J=8.5 \mathrm{~Hz}$, $2 \mathrm{H}), 7.33(\mathrm{~d}, J=8.5 \mathrm{~Hz}, 1 \mathrm{H}), 7.07(\mathrm{~d}, J=2.2 \mathrm{~Hz}, 1 \mathrm{H})$, $7.01(\mathrm{dd}, J=8.4,1.7 \mathrm{~Hz}, 1 \mathrm{H}), 4.54(\mathrm{~d}, J=5.4 \mathrm{~Hz}$, $2 \mathrm{H}) .{ }^{13} \mathrm{C}$ NMR $(100 \mathrm{MHz}, \mathrm{MeOD}): \delta 169.28,157.10$, $155.44,143.56,134.01,131.51,130.53,128.21$ (2C), 127.11, 118.42, 116.58, 115.18, 112.56, 40.73. HRMS (ESI, $m / z)$ : Calcd for $\mathrm{C}_{15} \mathrm{H}_{13} \mathrm{~F}_{3} \mathrm{NO}_{2} \quad\left([\mathrm{M}+\mathrm{H}]^{+}\right)$ 296.0893, found: 296.0887.

(d). Propionylpiperidine-4-carboxylic acid (3): To a stirred solution of methyl 4-piperidinecarboxylate (4.5 g, $30 \mathrm{mmol})$ in $\mathrm{CH}_{2} \mathrm{Cl}_{2}(10 \mathrm{~mL})$, propionyl chloride $(3.5 \mathrm{~mL}, 40 \mathrm{mmol})$ and triethyl amine $(5.6 \mathrm{~mL}, 37$ mmol) were added slowly at $0{ }^{\circ} \mathrm{C}$. The reaction was continued at $0{ }^{\circ} \mathrm{C}$ for $4 \mathrm{~h}$. Then the reaction was quenched by adding water $(10 \mathrm{~mL})$, and extracted with $\mathrm{CH}_{2} \mathrm{Cl}_{2}(2 \times 20 \mathrm{~mL})$. The combined organic layer was washed with water, brine, dried over anhydrous $\mathrm{Na}_{2} \mathrm{SO}_{4}$ and filtered. After the solvent was removed under reduced pressure, methanol $(20 \mathrm{~mL})$ and aqueous $\mathrm{NaOH}(5.0 \mathrm{~N}, 20 \mathrm{~mL})$ were added to the residue. The resulted mixture was stirred at RT for 16 h. The methanol was removed under reduced pressure, and $\mathrm{pH}$ of the solution was adjusted to 6-7 with $5 \mathrm{~N}$ aqueous $\mathrm{HCl}$. The mixture was extracted with $\mathrm{CH}_{2} \mathrm{Cl}_{2}$ $(3 \times 50 \mathrm{~mL})$, and the combined organic layer was washed with water, brine, dried over anhydrous $\mathrm{Na}_{2} \mathrm{SO}_{4}$ and filtered. The solvent was evaporated under vacuum, and the crude product was purified by silica gel column chromatography with $\mathrm{PE} / \mathrm{EtOAc}$ (3:1) as eluent to afford 3 as a white solid $(5.11 \mathrm{~g}$, 88\%), mp 86.5-87.8 ${ }^{\circ} \mathrm{C} .{ }^{1} \mathrm{H}$ NMR $\left(600 \mathrm{MHz}, \mathrm{CDCl}_{3}\right)$ : $\delta 4.41(\mathrm{~d}, J=13.3 \mathrm{~Hz}, 1 \mathrm{H}), 3.82(\mathrm{~d}, J=13.6 \mathrm{~Hz}, 1 \mathrm{H})$, $3.16-3.11(\mathrm{~m}, 1 \mathrm{H}), 2.88-2.83(\mathrm{~m}, 1 \mathrm{H}), 2.60-2.56$ (m, 1H), $2.39-2.35(\mathrm{~m}, 2 \mathrm{H}), 1.98-1.96(\mathrm{~m}, 2 \mathrm{H}), 1.74$ - $1.63(\mathrm{q}, J=7.4 \mathrm{~Hz}, 2 \mathrm{H}), 1.15(\mathrm{t}, J=7.4 \mathrm{~Hz}, 3 \mathrm{H})$. (LC-MS, $m / z$ ): Calcd for $\mathrm{C}_{9} \mathrm{H}_{16} \mathrm{NO}_{3}\left([\mathrm{M}+\mathrm{H}]^{+}\right)$186.2, found: 186.4

(e). $\quad N$-(4-Methoxy-2-(trifluoromethyl)benzyl)-1propionylpiperidine-4-carboxamide (MPPA, 4): Compound $\mathbf{4}$ was prepared by following the synthesis 
procedure of compound 1. The crude product was purified by silica gel column chromatography with $\mathrm{CH}_{2} \mathrm{Cl}_{2} / \mathrm{CH}_{3} \mathrm{OH}(10: 1)$ as eluent to afford 4 as a white solid (0.26 g, 70\%), mp 132.4-136.9 ${ }^{\circ} \mathrm{C} .{ }^{1} \mathrm{H}$ NMR (600 $\left.\mathrm{MHz}, \mathrm{CDCl}_{3}\right): \delta 7.45(\mathrm{~d}, J=8.5 \mathrm{~Hz}, 1 \mathrm{H}), 7.16(\mathrm{~d}, J=$ $2.6 \mathrm{~Hz}, 1 \mathrm{H}), 7.02(\mathrm{dd}, J=8.5,2.6 \mathrm{~Hz}, 1 \mathrm{H}), 5.81(\mathrm{~s}$, $1 \mathrm{H}), 4.53(\mathrm{~d}, J=5.6 \mathrm{~Hz}, 2 \mathrm{H}), 3.83(\mathrm{~s}, 3 \mathrm{H}), 3.05-3.00$ $(\mathrm{m}, 1 \mathrm{H}), 2.65-2.00(\mathrm{~m}, 1 \mathrm{H}), 2.35-2.28(\mathrm{~m}, 3 \mathrm{H}), 1.91$ - $1.81(\mathrm{~m}, 2 \mathrm{H}), 1.70-1.57(\mathrm{~m}, 4 \mathrm{H}), 1.13(\mathrm{t}, J=7.4$, $3 \mathrm{H})$. (LC-MS, $m / z)$ : Calcd for $\mathrm{C}_{18} \mathrm{H}_{24} \mathrm{~F}_{3} \mathrm{~N}_{2} \mathrm{O}_{3}\left([\mathrm{M}+\mathrm{H}]^{+}\right)$ 373.4, found: 373.2

(f). $\quad N$-(4-Hydroxy-2-(trifluoromethyl)benzyl)-1propionylpiperidine-4carboxamide (5): Compound 5 was prepared by following the synthesis procedure of compound $\mathbf{2}$. The crude product was purified by silica gel column chromatography with $\mathrm{CH}_{2} \mathrm{Cl}_{2} / \mathrm{CH}_{3} \mathrm{OH}$ (8:1) as eluent to afford $\mathbf{5}$ as a white solid $(17 \mathrm{mg}$, 55\%), mp 142.5-145.3 ${ }^{\circ} \mathrm{C}$. ${ }^{1} \mathrm{H}$ NMR (600 MHz, DMSO-d6): $\delta 8.29(\mathrm{t}, J=5.5 \mathrm{~Hz}, 1 \mathrm{H}), 7.23(\mathrm{~d}, J=$ $8.5 \mathrm{~Hz}, 1 \mathrm{H}), 7.03(\mathrm{~d}, J=2.2 \mathrm{~Hz}, 1 \mathrm{H}), 6.98$ (dd, $J=$ $8.5,1.7 \mathrm{~Hz}, 1 \mathrm{H}), 4.29(\mathrm{~d}, J=5.2 \mathrm{~Hz}, 2 \mathrm{H}), 3.86(\mathrm{~d}, J=$ $13.5 \mathrm{~Hz}, 1 \mathrm{H}), 2.98(\mathrm{t}, J=12.3 \mathrm{~Hz}, 1 \mathrm{H}), 2.54(\mathrm{t}, J=11.4$ $\mathrm{Hz}, 1 \mathrm{H}), 2.47-2.42(\mathrm{~m}, 1 \mathrm{H}), 2.34-2.25(\mathrm{~m}, 2 \mathrm{H}), 1.72$ $(\mathrm{t}, J=14.6 \mathrm{~Hz}, 2 \mathrm{H}), 1.53-1.23(\mathrm{~m}, 2 \mathrm{H}), 0.97(\mathrm{t}, J=$ $7.4 \mathrm{~Hz}, 3 \mathrm{H}) .{ }^{13} \mathrm{C}$ NMR (100 MHz, MeOD): $\delta 175.63$, $173.32,156.78,131.22,126.49,124.38,118.44$, $118.16,112.46,44.89,42.37,41.08,39.11,28.79$, 28.21, 25.88, 8.59. HRMS (ESI, $\mathrm{m} / \mathrm{z}$ ): Calcd for $\mathrm{C}_{17} \mathrm{H}_{22} \mathrm{~F}_{3} \mathrm{~N}_{2} \mathrm{O}_{3}\left([\mathrm{M}+\mathrm{H}]^{+}\right)$359.1577, found: 359.1569 .

(g). $N-\left(4-\left[{ }^{l l} \mathrm{C}\right]\right.$ methoxy-2(trifluoromethyl)benzyl)benzamide $\left(\left[{ }^{11} \mathrm{C}\right] 1\right)$ and $N-(4-$ $\left[{ }^{I l} \mathrm{C}\right]$ methoxy-2-(trifluoromethyl)benzyl)-1-

propionylpiperidine-4-carboxamide $\quad\left(\left[{ }^{11} C\right] M P P A\right.$, $\left.\left[{ }^{11} \mathrm{C}\right] 4\right):\left[{ }^{11} \mathrm{C}\right] \mathrm{CO}_{2}$ was produced by the ${ }^{14} \mathrm{~N}(\mathrm{p}, \alpha){ }^{11} \mathrm{C}$ nuclear reaction in the small volume $\left(9.5 \mathrm{~cm}^{3}\right)$ aluminum gas target provided with the Siemens RDS111 Eclipse cyclotron. The target gas consisted of $1 \%$ oxygen in nitrogen purchased as a specialty gas from Praxair, Indianapolis, IN. Typical irradiations used for the development were $58 \mu \mathrm{A}$ beam current and $20 \mathrm{~min}$ on target. The production run produced approximately $37.0 \mathrm{GBq}$ of $\left[{ }^{11} \mathrm{C}\right] \mathrm{CO}_{2}$ at EOB. The precursor $\mathbf{2}$ or $\mathbf{5}$ (0.1-0.3 mg) was dissolved in $\mathrm{CH}_{3} \mathrm{CN}(500 \mu \mathrm{L})$. To this solution was added aqueous $\mathrm{NaOH}(2 \mathrm{~N}, 2 \mu \mathrm{L})$. The mixture was transferred to a small reaction vial. No-carrier-added (high molar activity) $\left[{ }^{11} \mathrm{C} \mathrm{CH}_{3} \mathrm{OTf}\right.$ that was produced by the gas-phase production method ${ }^{37}$ within $12 \mathrm{~min}$ from $\left[{ }^{11} \mathrm{C}^{1} \mathrm{CO}_{2}\right.$ through $\left[{ }^{11} \mathrm{C}_{\mathrm{CH}_{4}}\right.$ and $\left[{ }^{11} \mathrm{C}\right] \mathrm{CH}_{3} \mathrm{Br}$ with AgOTf column was passed into the reaction vial at RT until radioactivity reached a maximum ( $2 \mathrm{~min}$ ), and then the reaction vial was isolated and heated at $80{ }^{\circ} \mathrm{C}$ for $3 \mathrm{~min}$. The contents of the reaction vial were diluted with aqueous $\mathrm{NaHCO}_{3}(0.1 \mathrm{M}, 1 \mathrm{~mL})$. The reaction vial was connected to a 3-mL HPLC injection loop. The labeled product mixture solution was injected onto the semi-preparative HPLC column for purification. The product fraction was collected in a recovery vial containing $30 \mathrm{~mL}$ water. The diluted tracer solution was then passed through a C-18 Plus Sep-Pak cartridge, and washed with water $(3 \times 10 \mathrm{~mL})$. The cartridge was eluted with EtOH $(3 \times 0.4 \mathrm{~mL})$ to release the labeled product, followed by saline (10-11 $\mathrm{mL})$. The eluted product was then sterile-filtered through a Millex-FG $0.2 \mu \mathrm{m}$ membrane into a sterile vial. Total radioactivity was assayed and total volume (10-11 mL) was noted for tracer dose dispensing. The overall synthesis time including HPLC-SPE purification and reformulation was 35-40 min from EOB. The decay corrected radiochemical yield was 25-35\%. Retention times in the analytical RP-HPLC system were: $t_{R} \mathbf{2}=3.57 \mathrm{~min}, t_{R} \mathbf{1}=6.56 \mathrm{~min}$, and $t_{R}$ $\left[{ }^{11} \mathrm{C}\right] \mathbf{1}=6.64 \mathrm{~min}$; and $\mathrm{t}_{\mathrm{R}} \mathbf{5}=2.76 \mathrm{~min}, \mathrm{t}_{\mathrm{R}} \mathbf{4}=4.23$ min, and $t_{R}\left[{ }^{11} \mathrm{C}\right] 4=4.31 \mathrm{~min}$. Retention times in the preparative RP-HPLC system were: $t_{R} \mathbf{2}=5.25$ min, $t_{R}$ $\mathbf{1}=7.67 \mathrm{~min}$, and $\mathrm{t}_{\mathrm{R}}\left[{ }^{11} \mathrm{C}\right] \mathbf{1}=7.74 \mathrm{~min}$; and $\mathrm{t}_{\mathrm{R}} \mathbf{5}=4.52$ $\min , t_{R} 4=6.78 \mathrm{~min}$, and $t_{R}\left[{ }^{11} \mathrm{C}\right] 4=6.83 \mathrm{~min}$. 